\title{
EFFICACY OF GREEN ONION ROOT EXTRACT IN COSMETICS AND SKIN CARE PRODUCTS
}

\author{
EFICÁCIA DO EXTRATO DE RAIZ DE CEBOLA VERDE EM COSMÉTICOS E \\ PRODUTOS DE CUIDADO DA PELE
}

\author{
Li Hsien CHEN'; I Chia CHEN'; Pei Yen CHEN'; Ping Hsin Huang ${ }^{1 *}$ \\ 1. Department of Cosmetic Applications and Management, College of Cardinal Tien Junior College of Healthcare and Management. \\ *pshuang@ctcn.edu.tw
}

\begin{abstract}
In this study, leftover roots of Sansing green onions grown without toxic chemicals in Sansing Township, Ilan County, Taiwan were used as a raw material of skincare products. The raw material was extracted from the green onion roots by ultrasound in a low-temperature, safe and pollution-free environment. We hope to develop cleansers and other facial care products made of this natural, environmentally friendly, safe and affordable raw material so that people with sensitive skin can also use these products. We also hope that this study can contribute to circular economy and achieve the goal of green innovation by recycling the leftover roots. In terms of anti-oxidation, the DPPH free radical scavenging ability of $2.5 \mathrm{mg} / \mathrm{mL}$ green onion root extract was equivalent to $98 \%$ of that of $1 \mathrm{mg} / \mathrm{mL} \mathrm{BHT}$; the $\mathrm{Fe}^{2+}$ chelating ability was equivalent to $87.0 \%$ of that of $0.02 \mathrm{mg} / \mathrm{mL}$ EDTA; the superoxide anions scavenging ability of 2.5 $\mathrm{mg} / \mathrm{mL}$ green onion root extract was equivalent to $84.2 \%$ of that of $1 \mathrm{mg} / \mathrm{mL}$ BHT and $80.4 \%$ of that of 0.05 $\mathrm{mg} / \mathrm{mL}$ vitamin $\mathrm{C}$. With respect to melanin synthesis inhibition, the green onion root extract's ability to inhibit dopachrome, the intermediate product of melanin, was positively correlated to its concentration, i.e., the higher the concentration of the green onion root extract, the better the inhibition ability. The $\mathrm{IC}_{50}$ of green onion root extract was $1.83 \mathrm{mg} / \mathrm{mL}$, while, for comparison, the $\mathrm{IC}_{50}$ of vitamin $\mathrm{C}$ was $0.62 \mathrm{mg} / \mathrm{mL}$. Furthermore, according to the cell survival assay, no obvious cytotoxic effect was found with the increase in the concentration of the green onion root extract. The whitening effect improved after 30 days of test. The improvement rate was $5.6 \%$ for $2.5 \mathrm{mg} / \mathrm{mL}$ green onion root extract, $3.1 \%$ for $1.25 \mathrm{mg} / \mathrm{mL}$ extract, and $1.7 \%$ for $0.625 \mathrm{mg} / \mathrm{mL}$ extract. The moisture retention also improved after 30 days of test. The moisture retention improvement rate was $22.7 \%$ for $2.5 \mathrm{mg} / \mathrm{mL}$ green onion root extract, $21.6 \%$ for $1.25 \mathrm{mg} / \mathrm{mL}$ extract, and $15.4 \%$ for $0.625 \mathrm{mg} / \mathrm{mL}$ extract. Based on the experiments, the green onion root extract obtained from ultrasound not only did not cause skin allergy and irritation but also showed anti-aging, melanin synthesis inhibition, whitening and moisture retention effects. The results showed that the green onion root extract can improve the moisture retention and whitening effect of the mask.
\end{abstract}

KEYWORDS: Green Onion Root. Extraction. Circular Economy. Anti-oxidation. Anti-aging. Whitening. Cosmetics.

\section{INTRODUCTION}

Green onion (scientific name: Allium fistulosum) contains nutrients, such as minerals, vitamin $\mathrm{C}, \beta$-carotene and dietary fiber; 100 grams of green onion contain 3.5 grams of dietary fiber, making green onion a high-fiber vegetable (CHIOU, 2010; JIANG, 1992; KUNG, 2001; MURAI et al., 1981; WU, 2010; YAMASAKI et al., 2000; ZHONG, 1993). The epidermal cells of green onion contain a large number of bactericidal allicin, malic acid and phosphate sugar, while the prostaglandin it contains can enhance blood circulation, help perspiration and diuresis, prevent dizziness caused by high blood pressure and help prevent dementia. The pungent odor of green onions comes from allicin, which is an antibacterial, bactericidal and mucolytic volatile component (HSIAO, 2004; HUANG, 1999; RAJU et al., 2007; JIANG, 1992; CHEN, 1999; SU, 2003). The viscous colloidal liquid squeezed from the stems of green onions is able to repair and heal skin wounds. In East Asian and Chinese regions, green onion is a common spice or vegetable. It plays an important role in oriental cooking, but only stems and leaves are consumed; the roots are usually discarded (ZHONG, 1993; HUANG, 2007; CHANG, 2011; HUANG, 2015).

The green onion roots contain protein, carbohydrate, vitamin A, dietary fiber, and minerals, such as phosphorus, iron, and magnesium. Green onion roots were cooked in chicken soup by farmers in Taiwan, or were applied to the skin to reduce inflammation and swelling (GREATENS, et al., 2005; HSU, 2012; LERNER, et al., 1950; LIN, 
2003; HSIAO, 2004; HSU, 2012; MAYER, et al., 1986). It is a waste if the green onion roots are discarded or composted. The objective of this study was to explore whether we can make good use of the highly nutritious leftover green onion roots.

The organic green onion roots were obtained after several times of communication with local green onion farmers and on-site visits, and then they were extracted by ultrasonic low- temperature extraction technology to generate the organic green onion root extract. The anti-oxidation, melanin removal, cytotoxicity, and whitening effects of the green onion root extract were assessed before we developed new skincare products by adding the natural green onion root extract (Figure 1). We hope to make the green onion roots recycling a step forward towards a green circular economy and diverse agricultural development.

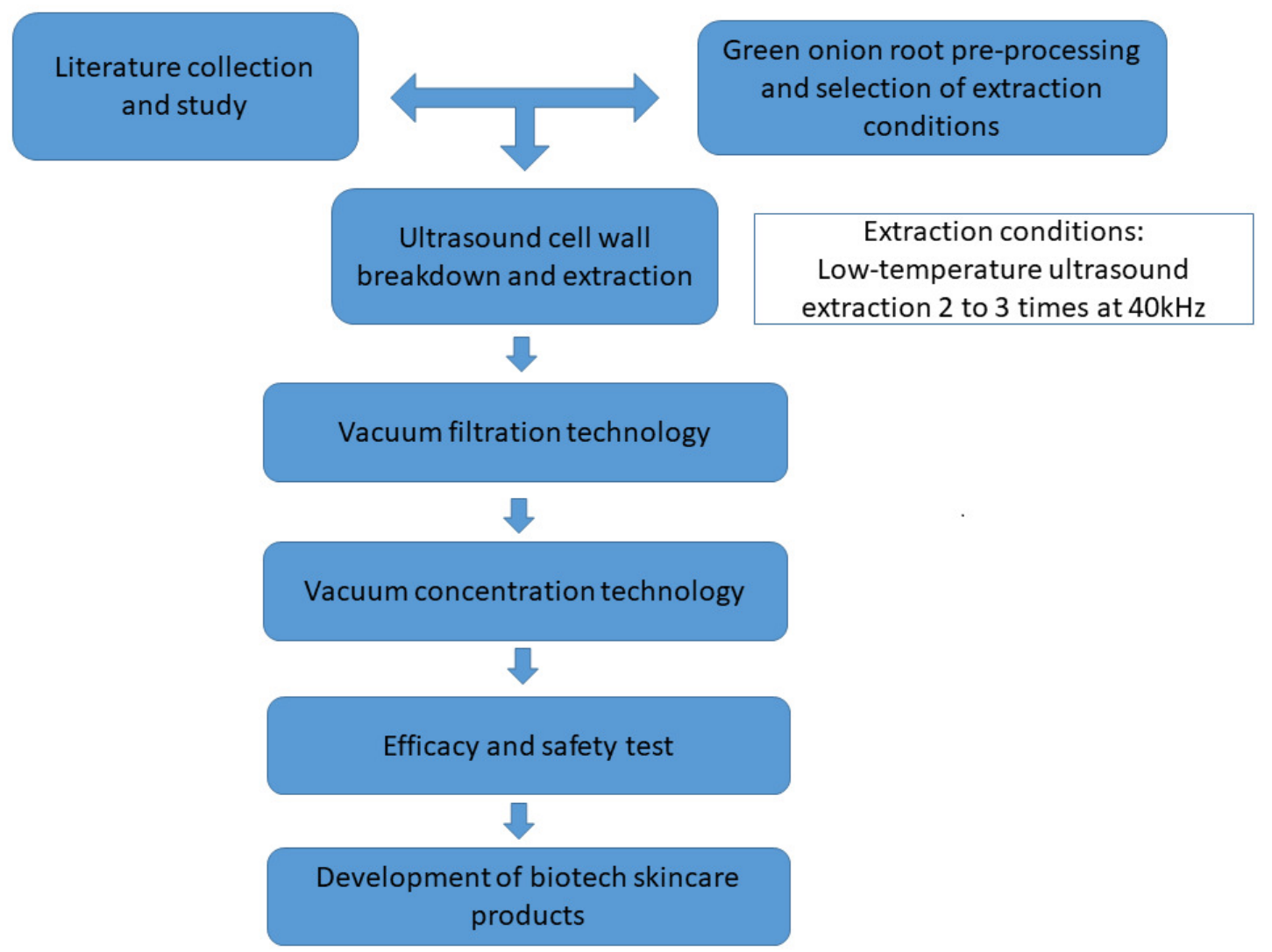

Figure 1. Development of biotech skincare products containing the green onion root extract

\section{MATERIAL AND METHODS}

\section{Preparation of the green onion root extract}

The raw material was the green onion roots cut off from the green onions grown without toxic chemicals in Sansing Township, Ilan County, Taiwan. The usable roots were cleaned thoroughly with deionized water before being soaked in alcohol for three times, each time for three minutes. Next, the green onion roots were dried at low temperature, and then smashed to increase the area for oscillation. Ethanol was added as a solvent before the whole solution was oscillated by $40 \mathrm{kHz}$ ultrasound, which produced numerous tiny vacuum bubbles in the medium. When the tiny vacuum bubbles popped (cavitation effect), the resulting impact enhanced the effect of extraction.
Because high-frequency and short-wave length ultrasound has greater penetration power, it allowed the extract to be fully mixed, which in turn increased the extraction rate. The extraction rate was $33.8 \%$ after filtration, concentration and freezedrying.

\section{DPPH free radical scavenging ability}

The method was performed as described by Yamaguchi et al., (1998). A mixture of $100 \mu \mathrm{L}$ green onion root extract, $400 \mu \mathrm{L}$ of $100 \mathrm{mM}$ Tris$\mathrm{HCl}$ buffer $(\mathrm{pH}=7.4)$ and $500 \mu \mathrm{L}$ of $250 \mu \mathrm{M} \mathrm{DPPH}$ free radical ethanol solution was well mixed in a microcentrifuge tube before the tube was placed in a $25^{\circ} \mathrm{C}$ thermostatic reactor for 20 minutes. Then, the tube was transferred to a UV- Vis spectrophotometer for measuring $\mathrm{OD}_{517}$ of the 
solution. The procedure was repeated for three times. The DPPH free radical scavenging rate is calculated by the following formula:

DPPH free radical scavenging rate $(\%)=[1-$ $\left(\mathrm{OD}_{517}\right.$ of sample/OD $\mathrm{O}_{517}$ of blank solution] $\times 100 \%$

\section{$\mathrm{Fe}^{2+}$ chelating ability}

The method was performed as described by Dinis et al., (1994). First, add $0.1 \mathrm{~mL}$ green onion root extract, $3.7 \mathrm{~mL}$ of $95 \%$ ethanol and $0.1 \mathrm{~mL}$ of 2 $\mathrm{mM} \mathrm{FeCl} 2 \cdot 4 \mathrm{H}_{2} \mathrm{O}$ solution to a sample bottle, and let the solution sit for 30 seconds at room temperature. Then, add $0.2 \mathrm{~mL}$ of $5 \mathrm{mM}$ ferrozine solution to the same sample bottle, and let the solution react for 10 minutes at room temperature. Measure $\mathrm{OD}_{562}$ of the sample by the UV- Vis spectrophotometer. The procedure was repeated for three times. The $\mathrm{Fe}^{2+}$ chelating ability is calculated by the following formula:

The $\mathrm{Fe}^{2+}$ chelating ability $(\%)=[1-(\mathrm{OD} 562$ of sample/ OD562 of blank solution] $\times 100 \%$

\section{Superoxide anions scavenging ability $\left(\mathrm{O}_{2}{ }^{\circ}-\right)$}

The method was performed as described by Fried et al., (1996). First, add $0.25 \mathrm{~mL}$ green onion root extract and $1 \mathrm{~mL}$ mixture solution (a mixture of $100 \mu \mathrm{l}$ of $10 \mu \mathrm{M}$ PMS, $50 \mu \mathrm{l}$ of $78 \mu \mathrm{M}$ NADH and $100 \mu$ of $50 \mu \mathrm{M}$ NBT with $\mathrm{pH} 7.4,0.1 \mathrm{M}$ phosphate buffer to $1 \mathrm{~mL}$ ) to a sample bottle, and then place the sample bottle in a thermostatic water bath at $25^{\circ} \mathrm{C}$ for 10 minutes. Next, add $0.25 \mathrm{~mL}$ of 1.2 units $/ \mathrm{mL}$ xanthine oxidase to the bottle, and let the solution react for two minutes in the $25^{\circ} \mathrm{C}$ thermostatic water bath. Measure $\mathrm{OD}_{532}$ of the sample by the UV- Vis spectrophotometer (At). Next, replace xanthine oxidase with $0.1 \mathrm{M}$ Tris- $\mathrm{HCl}$ buffer $(\mathrm{pH}=7.4)$, and then measure $\mathrm{OD}_{532}$ of the sample $\left(\mathrm{A}_{1}\right)$. Then, replace the sample with DMSO, and then measure the $\mathrm{OD}_{532}$ of DMSO $\left(\mathrm{A}_{\mathrm{b}}\right)$. Finally, replace the sample and xanthine oxidase with DMSO and phosphate buffer solution, respectively, and then measure $\mathrm{OD}_{532}$ of the solution $\left(\mathrm{A}_{0}\right)$. Use vitamin $\mathrm{C}$ and $\mathrm{BHT}$ as positive reaction control groups. The $\mathrm{O} 2{ }^{\circ}-$ scavenging rate is calculated by the following formula:

$$
\begin{aligned}
& \mathrm{O}_{2}{ }^{\circ} \quad \text { scavenging } \quad \text { rate }= \\
& \left.\left(\mathrm{A}_{\mathrm{b}}-\mathrm{A}_{0}\right)-\left(\mathrm{A}_{\mathrm{t}}-\mathrm{A}_{1}\right) /\left(\mathrm{A}_{\mathrm{b}}-\mathrm{A}_{0}\right)\right] \times 100 \%
\end{aligned}
$$

\section{Melanin synthesis inhibition ability}

The method was performed as described by Lee et al., (1997). Well mix $1 \mathrm{~mL}$ of green onion root extract, $0.9 \mathrm{~mL}$ of phosphate buffer solution $(\mathrm{pH}=6.8)$ and $1 \mathrm{~mL}$ of $0.03 \%$ tyrosine aqueous solution in a sample bottle, and then place the bottle in a thermostatic water bath at $37^{\circ} \mathrm{C}$ for 10 minutes. Next, add $0.1 \mathrm{~mL}$ of 350 units $/ \mathrm{mL}$ tyrosinase to the solution, and let the well-mixed solution react in the thermostatic water bath for 25 minutes. Measure $\mathrm{OD}_{475}$ of the solution by the UV-Vis spectrophotometer $\left(A_{t}\right)$. Then, replace tyrosinase with phosphate buffer solution, and then measure $\mathrm{OD}_{475}$ of the solution $\left(\mathrm{A}_{1}\right)$. Next, replace the green onion root extract with deionized water, and then measure $\mathrm{OD}_{475}$ of the solution $\left(\mathrm{A}_{\mathrm{b}}\right)$. Finally, replace the green onion root extract and tyrosinase with distilled water and phosphate buffer solution, respectively, and then measure $\mathrm{OD}_{475}$ of the solution $\left(\mathrm{A}_{0}\right)$. The procedure was repeated for three times. The dopachrome inhibition rate is calculated by the following formula:

Dopachrome inhibition rate $(\%)=$

$\left[\left(\mathrm{A}_{\mathrm{b}}-\mathrm{A}_{0}\right)-\left(\mathrm{A}_{\mathrm{t}}-\mathrm{A}_{1}\right) /\left(\mathrm{A}_{\mathrm{b}}-\mathrm{A}_{0}\right)\right] \times 100 \%$

$\mathrm{IC}_{50}(50 \%$ inhibition concentration) is the concentration of green onion root extract that inhibits $50 \%$ of dopachrome synthesis. It was obtained by a linear regression curve constructed based on the dopachrome inhibition rate under different concentration of the green onion root extract.

\section{Cell survival assay}

The method was performed as described by Kazuho et al., (1999). Cell survival assay is usually performed using 3-(4,5-dimethylthiazol-2-yl)-2,5diphenyl- tetrazolium bromide (MTT). Therefore, this assay is called MTT test or Tetrazolium assay. MTT is a yellow water-soluble substance that can be metabolized by dehydrogenase in mitochondria in cells. The activity of dehydrogenase is positively correlated with cellular respiration. Therefore, we can measure cell activities by following this principle. When the tetrazolium ring of MTT is cut off by dehydrogenase, the MTT is reduced to purple crystal formazan (3-[4,5-dimethylthiazol-2-yl]-2,5diphenyl-formazan), which accumulates in the cells. Formazan is soluble in DMSO and its concentration can be measured by a spectrophotometer at $570 \mathrm{~nm}$. The higher the cell survival rate is or the more the cell number is, the more accumulated purple crystal is. Therefore, MTT test is often used to assess the cell survival rate. Five milligrams of 3-(4,5dimethylthiazol-2-yl)-2,5-diph-enyl-tetrazolium bromide (MTT) was dissolved in $1 \mathrm{~mL}$ sterile PBS and filtered by a $0.45 \mu \mathrm{m}$ membrane before it was stored at $4^{\circ} \mathrm{C}$. Mouse fibroblast 3T3 cells were cultured in a 96-well plate $(1 \times 105$ cells/0.1 
$\mathrm{mL} /$ well). After 24 hours, the old culture medium was aspirated and culture media of different concentration were added to the plate. After 24 hours of incubation, the old culture media were aspirated. The cells were rinsed with PBS twice and $100 \mu \mathrm{L}$ MTT $(0.5 \mathrm{mg} / \mathrm{mL})$ was added to the cells. Then, the cells were incubated in a $37^{\circ} \mathrm{C}$ incubator with $5 \% \mathrm{CO}_{2}$ for one hour. Finally, the old culture medium was aspirated before $100 \mu \mathrm{L}$ DMSO was added to the culture, and then the culture was left for 10 minutes. The absorbance of the culture was measured by a spectrophotometer at $570 \mathrm{~nm}$.

Cell proliferation $(\%)=($ O.D sample/O.D control) $\times 100 \%$

\section{Whitening effect and moisture retention assay}

(1) Instrument name: three-in-one skin analyzer (SSC3);

(2) Brand: Courage-Khazaka Electronic Gmbh (CK), Germany

(3) Test methods:

1. The protocol number of the Human Research Ethics Committee for this research: 201705ES002

2. Sampling: sample onion root extract solutions of $2.50 \mathrm{mg} / \mathrm{mL}, 1.25 \% \mathrm{mg} / \mathrm{mL}$, $0.625 \% \mathrm{mg} / \mathrm{mL}, 0.312 \mathrm{mg} / \mathrm{mL}$ and 0.156 $\mathrm{mg} / \mathrm{mL}$.

3. Test spots: forehead and cheek.

4. Test age/skin: 18 to 20 years old females.

5. Test environment: thermostatic indoor temperature at $20^{\circ} \mathrm{C}$.

6. Test area: the test areas were divided into experimental area and control area. Right side was an experimental area (for cleansing mousse containing the green onion root extract), and the left side was a control area (for cleansing mousse without the green onion root extract).

7. Application time: clean the entire face first. After 30 minutes, apply the cleansing mousse containing the green onion root extract to $1 \mathrm{~cm}^{2}$ skin area on the right side of the face and add the cleansing mousse without green onion root extract to $1 \mathrm{~cm}^{2}$ skin area on the left side of the face. Wait for 60 minutes before testing.

\section{RESULTS AND DISCUSSION}

\section{DPPH free radical scavenging ability of the green onion root extract}

DPPH free radicals are stable free radicals containing odd number of electrons. When they are combined with other free radicals or reduced by antioxidants, DPPH free radicals are scavenged $(\mathrm{DPPH} \cdot+\mathrm{AH} \rightarrow \mathrm{DPPH}-\mathrm{H}+\mathrm{A} \cdot)$, and the color is turned from purple to light yellow, which in turn reduces the absorbance. The lower the absorbance is, the stronger the sample's DPPH free radical scavenging ability is and the stronger the antioxidation ability is. DPPH - ethanol solution has very strong absorbance at $517 \mathrm{~nm}$ visible light.

Figure 2 shows the DPPH free radical scavenging ability of green onion root extract on DPPH free radicals. The DPPH free radical scavenging ability of green onion root extract increased as the concentration of green onion root extract increased. The DPPH free radical scavenging ability of $0.625 \mathrm{mg} / \mathrm{mL}$ green onion root extract was $18.9 \%$, and that of $1.25 \mathrm{mg} / \mathrm{mL}$ and $2.5 \mathrm{mg} / \mathrm{mL}$ green onion root extract was $30.4 \%$ and $48.6 \%$, respectively, about $98 \%$ of that of $1 \mathrm{mg} / \mathrm{mL}$ BHT.

\section{$\mathrm{Fe}^{2+}$ chelating ability}

In addition to the formation of hydroxyl radicals $(\cdot \mathrm{OH})$ by Fenton reaction, the ferrous ions $\left(\mathrm{Fe}^{2+}\right)$ in the body also reacts with lipid peroxides $(\mathrm{LOOH})$, resulting in oxidative lipid free radicals $\left(\mathrm{LO}^{*}\right)$. Therefore, substrates with iron chelating ability can also act as antioxidant synergists. Therefore, if the green onion root extract has iron chelating activity, it can act as an antioxidant. $\mathrm{Fe}^{2+}$ can form a complex with ferrozine, and the maximum absorbance of such complex is at $562 \mathrm{~nm}$. The lower the absorbance is, the stronger the sample's $\mathrm{Fe}^{2+}$ chelating ability is. Figure 3 shows the green onion root extract's chelating ability against $\mathrm{Fe}^{2+}$. Such ability increased as the concentration of the green onion root extract increased. The $\mathrm{Fe}^{2+}$ chelating ability of $2.5 \mathrm{mg} / \mathrm{mL}$ green onion root extract was equivalent to $87.0 \%$ of that of $0.02 \mathrm{mg} / \mathrm{mL}$ EDTA. However, further studies are required to identify which component in the green onion root extract relates to $\mathrm{Fe}^{2+}$ chelating. 


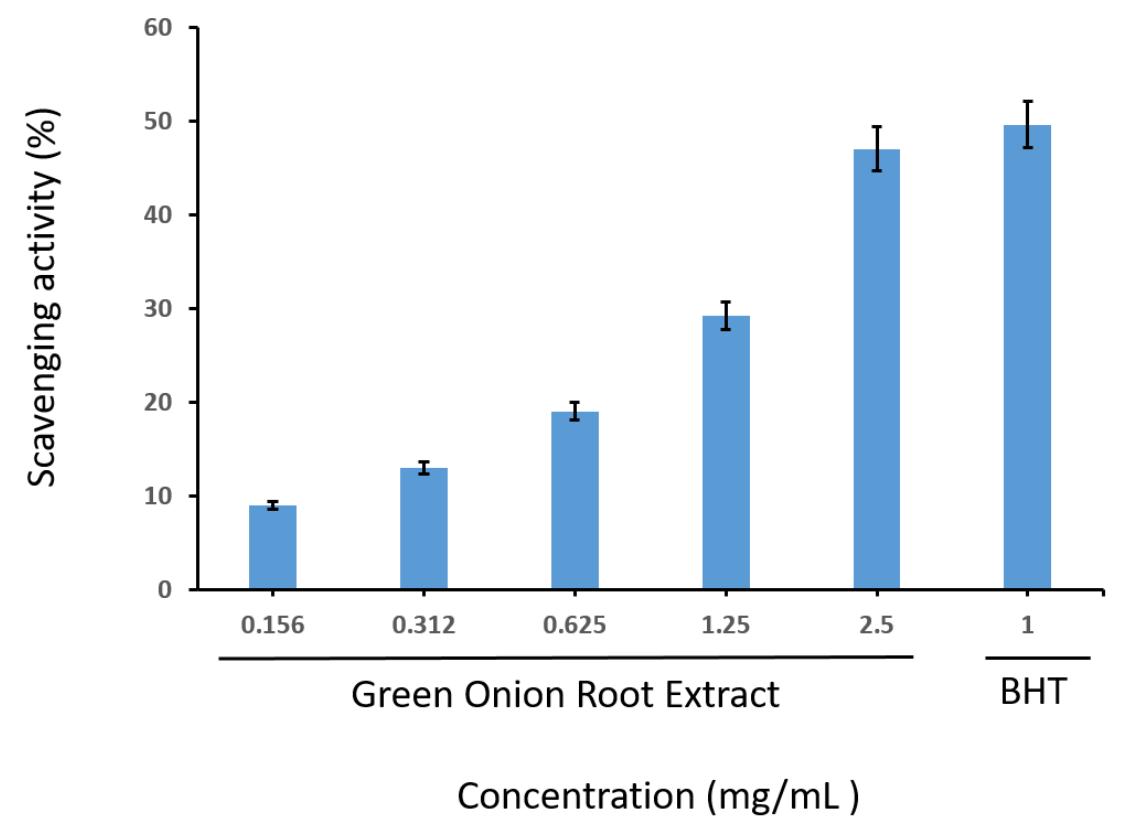

Figure 2. DPPH free radical scavenging capacity of green onion root extract at different concentration and that of $1 \mathrm{mg} / \mathrm{mL}$ BHT

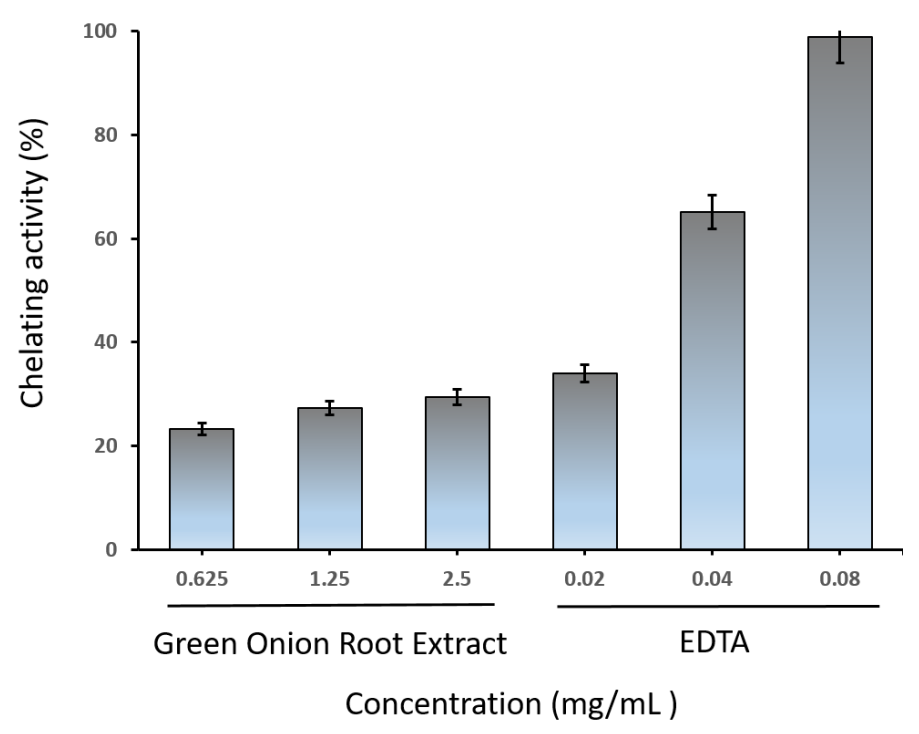

Figure 3. $\mathrm{Fe}^{2+}$ chelating ability of green onion root extract

\section{Superoxide anion scavenging ability}

In the process of in vivo metabolism, an oxygen molecule forms a superoxide anion with an electron through reduction reaction. The electron transfer chain reaction taking place on the inner mitochondrial membrane in the cytoplasm also results in superoxide anion formation. These processes give rise to $\mathrm{O}_{2}{ }^{\circ}$ - free radicals, which damage human cells. Therefore, $\mathrm{O}_{2}{ }^{\circ}-$ scavenging substrates can act as antioxidants to reduce oxidative damage. The oxidation of xanthine by xanthine oxidase generates $\mathrm{O}_{2}{ }^{-}$, which reduces nitroblue tetrazolium in the reaction reagent to formazan. The maximum absorbance of formazan is at $532 \mathrm{~nm}$. The lower the $\mathrm{OD}_{532}$ value is, the better the sample's scavenging ability is. Figure 4 shows the $\mathrm{O}_{2}{ }^{\circ}$ - scavenging ability of green onion root extract. It increased as the concentration of green onion root extract increased. The $\mathrm{O}_{2}{ }^{-}$- scavenging ability of $2.5 \mathrm{mg} / \mathrm{mL}$ green onion root extract was equivalent to $84.2 \%$ of that of $1 \mathrm{mg} / \mathrm{mL}$ BHT and $80.4 \%$ of that of $0.05 \mathrm{mg} / \mathrm{mL}$ Vit. C. 


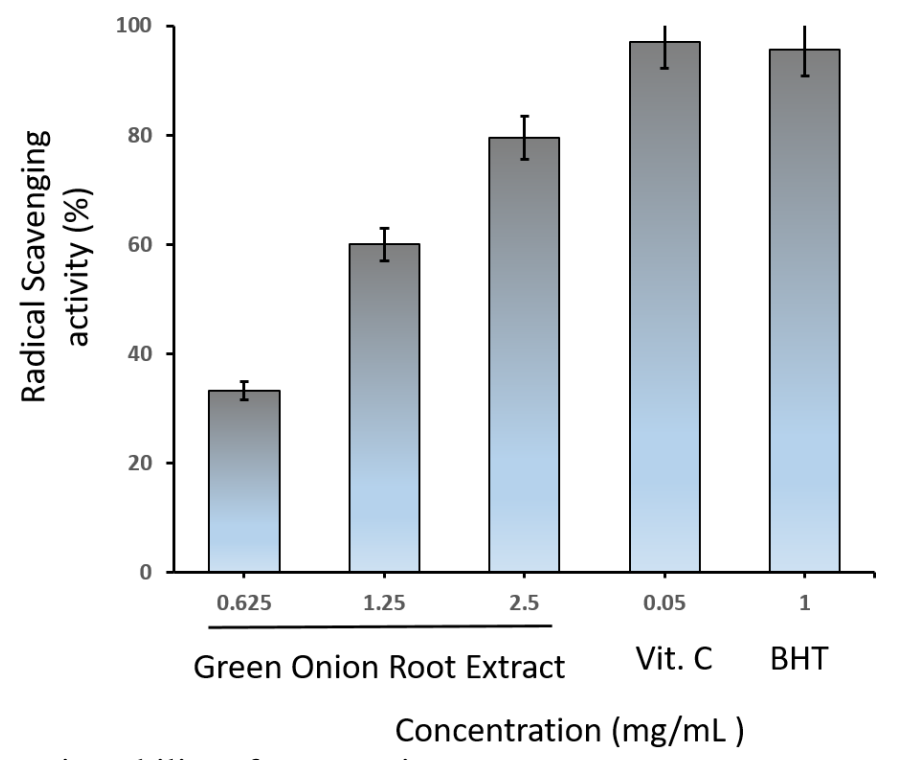

Figure 4. $\mathrm{O}_{2}{ }^{\circ}$ - scavenging ability of green onion root extract

The ability of green onion root extract to inhibit melanin synthesis

In the process of melanin synthesis, tyrosine is turned into dopaquinone through the catalysis of tyrosinase. Dopaquinone then forms melanin through a series of reactions. Dopachrome is a more stable intermediate in the process of melanin synthesis, and its maximum absorbance is at 475 $\mathrm{nm}$. The lower the $\mathrm{OD}_{475}$ is, the better the sample's ability to inhibit melanin synthesis. Figure 5 shows the inhibition of tyrosinase activity by the green onion root extract. According to Figure 4, the green onion root extract's ability to inhibit tyrosinase activity increases with its concentration, i.e., they are positively correlated, and the $\mathrm{IC}_{50}$ was 1.83 . $\mathrm{Mg} / \mathrm{mL} . \mathrm{Cu}^{2+}$ is a cofactor of tyrosinase. It catalyzes the oxidation reaction of melanin synthesis. If the sample has metal ion chelating ability, it can inhibit melanin synthesis. According to the results of the anti-oxidation test, the green onion root extract was able to chelate metal irons. Therefore, we inferred that the green onion root extract's ability to inhibit dopachrome synthesis is related to its $\mathrm{Cu}^{2+}$ chelating ability.

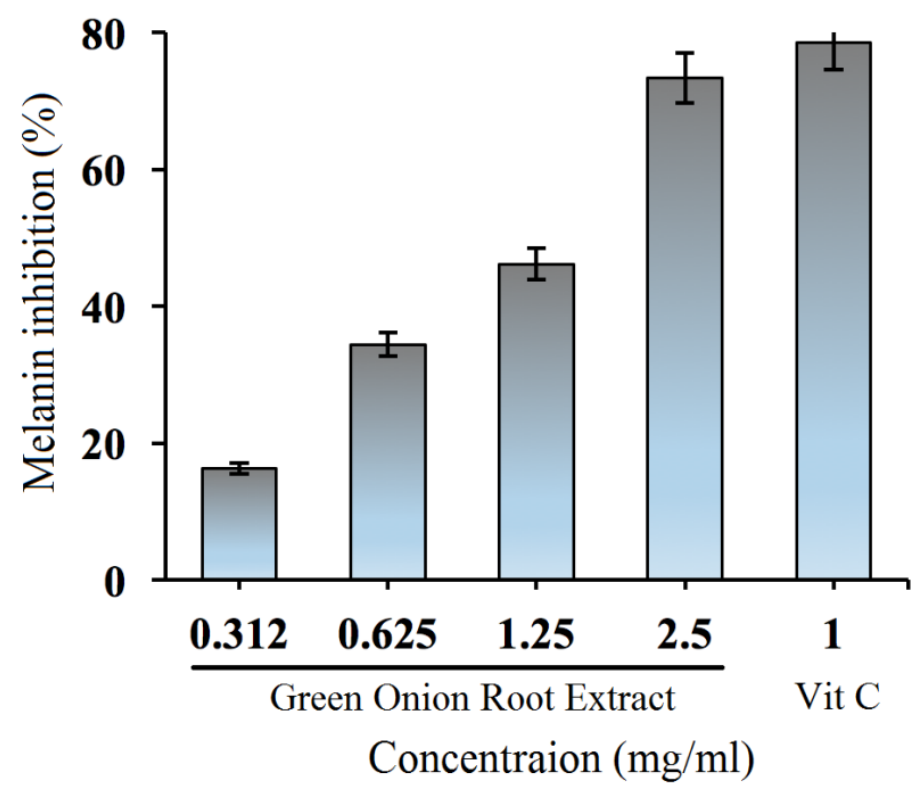

Figure 5. The melanin synthesis inhibition ability of green onion root extract 


\section{Cell survival assay of green onion root extract}

MTT is a yellow water-soluble substrate that can be reduced to blue-violet crystals by dehydrogenase in mitochondria during cellular respiration. The blue-violet crystals accumulating in the cells can be dissolved by DMSO, and its absorbance can be measured at $540 \mathrm{~nm}$. The higher the cell survival rate is, the more the blue-violet crystals are produced and the higher the $\mathrm{OD}_{540}$ value is. In this study, the green onion root extract was tested using the cell survival assay. The objective was to observe whether the green onion root extract is toxic to the cells. Figure 6 is the survival rate of $3 \mathrm{~T} 3$ cells in the green onion root extract at different concentration. The results indicated that there was no obvious cytotoxic effect on the cells as the concentration of the green onion root extract and culture time increased.

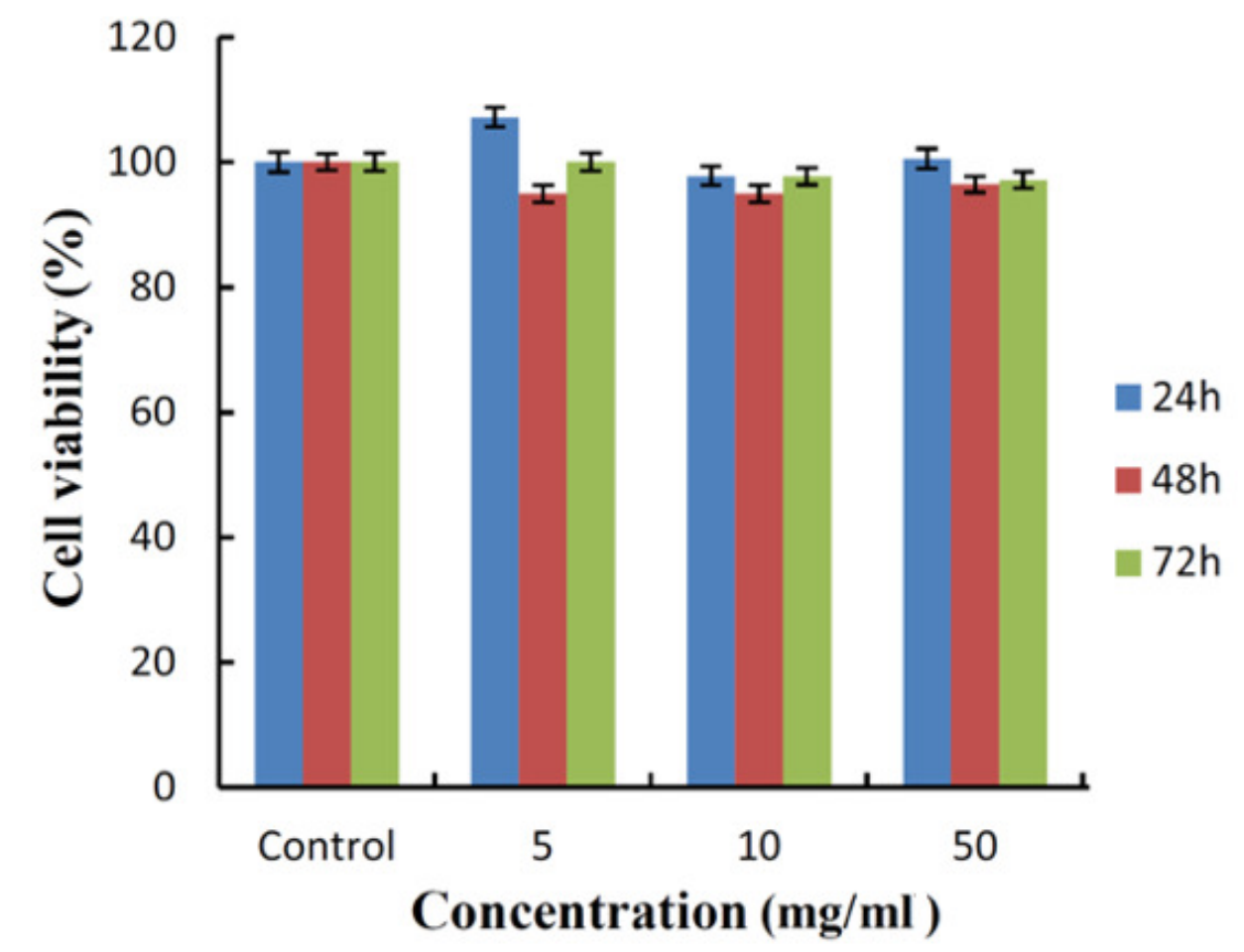

Figure 6. Cytotoxicity of the green onion root extract

\section{Assessment of moisturizing effect of green onion root extract}

The green onion root extract was diluted to $2.50 \mathrm{mg} / \mathrm{mL}, 1.25 \mathrm{mg} / \mathrm{mL}, 0.625 \mathrm{mg} / \mathrm{mL}, 0.312$ $\mathrm{mg} / \mathrm{mL}$, and $0.156 \mathrm{mg} / \mathrm{mL}$ with distilled water. The diluted solution at different concentration was applied to 20 subjects for the moisture retention assessment. The average values of the 20 subjects are shown in Table 1, Figure 7 and Figure 8. The moisture retention improvement rates after one hour and 30 days of use are shown in Table 2 and Table 3 , respectively.

Table 1. Green onion root extract moisture retention data of the experimental group and control group (average values of 20 subjects)

\begin{tabular}{lllll}
\hline & \multicolumn{2}{l}{ After 1 hour of use } & \multicolumn{2}{l}{ After 30 days of use } \\
\cline { 2 - 5 } Concentration $(\mathrm{mg} / \mathrm{mL})$ & Control & Experimental & Control & Experimental \\
\hline 2.50 & 23.6 & 24.5 & 39.2 & 48.1 \\
1.25 & 24.5 & 25.2 & 33.7 & 41.0 \\
0.625 & 19.7 & 20.2 & 27.2 & 31.4 \\
0.312 & 19.0 & 19.4 & 24.7 & 26.4 \\
0.156 & 22.8 & 23.2 & 23.5 & 24.6 \\
\hline
\end{tabular}




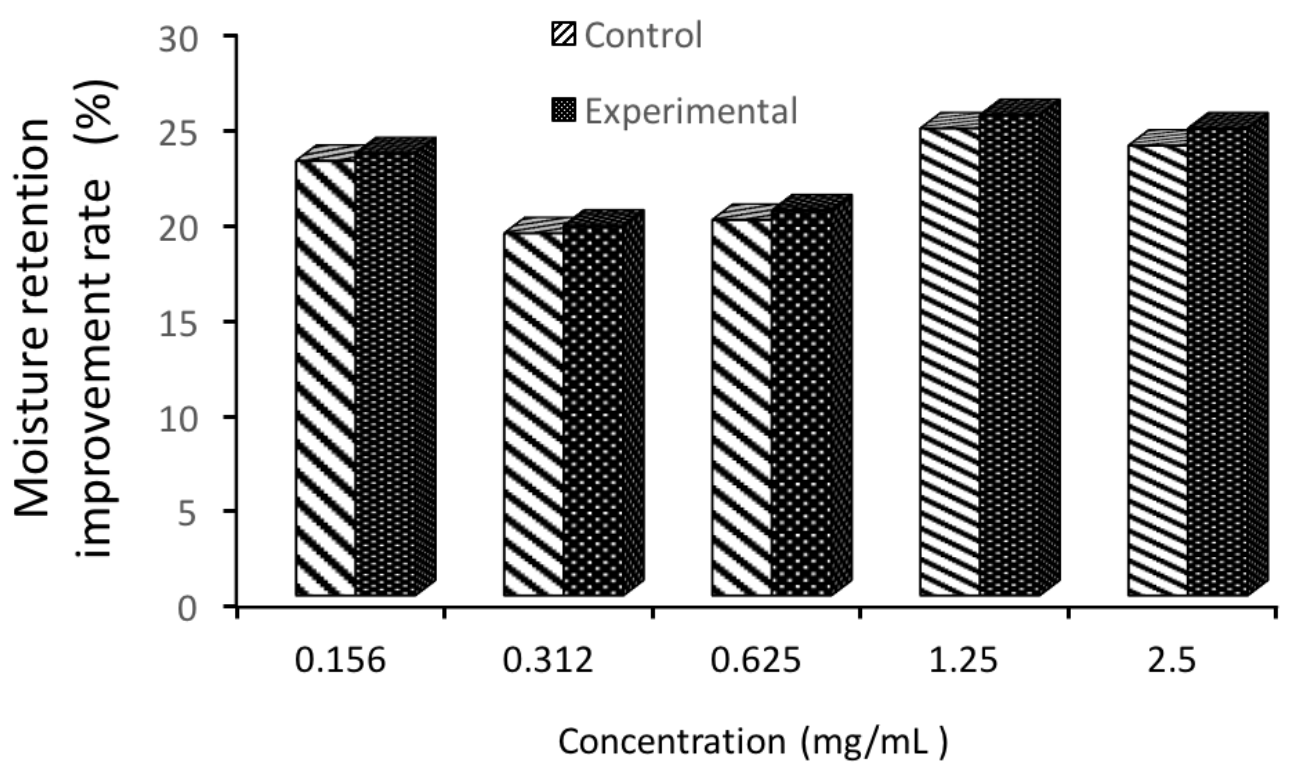

Figure 7. Moisture retention effect of the green onion extract after one hour of use

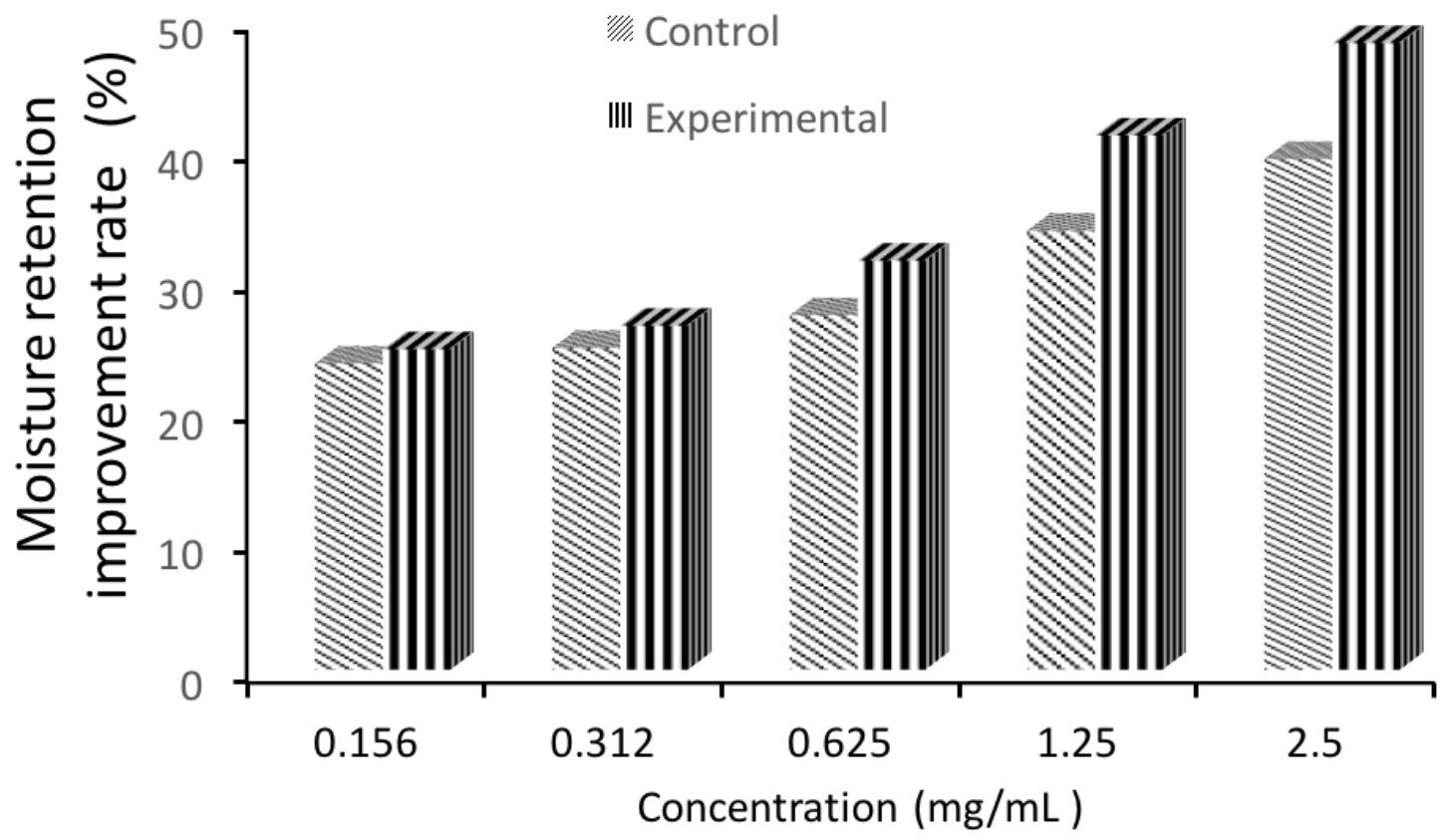

Figure 8. Moisture retention effect of the green onion extract after 30 days of use

Moisture retention improvement rate $=\frac{\text { Experimental Grup-Control Group }}{\text { Control Group }} \times 100 \%$

Table 2. Moisture retention improvement rate of the green onion root extract at different concentration after one hour of use

\begin{tabular}{llllll}
\hline $\begin{array}{l}\text { Concentration } \\
(\mathrm{mg} / \mathrm{mL})\end{array}$ & 2.50 & 1.25 & 0.625 & 0.312 & 0.156 \\
\hline $\begin{array}{l}\text { Improvement } \\
\text { rate }(\%)\end{array}$ & 3.38 & 2.86 & 2.53 & 2.11 & 1.75 \\
\hline
\end{tabular}


Efficacy of green...

CHEN, L. H. et al.

Table 3. Moisture retention improvement rate of the green onion root extract at different concentration after 30 days of use

\begin{tabular}{llllll}
\hline $\begin{array}{l}\text { Concentration } \\
(\mathrm{mg} / \mathrm{mL})\end{array}$ & 2.50 & 1.25 & 0.625 & 0.312 & 0.156 \\
\hline $\begin{array}{l}\text { improvement } \\
\text { rate }\end{array}$ & $22.7 \%$ & $21.6 \%$ & $15.4 \%$ & $6.8 \%$ & $4.7 \%$ \\
\hline
\end{tabular}

\section{Assessment of whitening effect of the green onion} root extract

The green onion root extract was diluted to $2.50 \mathrm{mg} / \mathrm{mL}, 1.25 \% \mathrm{mg} / \mathrm{mL}, 0.625 \% \mathrm{mg} / \mathrm{mL}, 0.312$ $\mathrm{mg} / \mathrm{mL}$, and $0.156 \mathrm{mg} / \mathrm{mL}$ with distilled water. The diluted solution at different concentration was applied to 20 subjects for the whitening effect assessment. The average values of the 20 subjects are shown in Table 4 and Figure 9. The whitening effect improvement rates after 30 days of use are shown in Table 5.

Table 4. Green onion root extract whitening effect data of the experimental group and the control group (average values of 20 subjects)

\begin{tabular}{llc}
\hline & \multicolumn{2}{c}{ After 30 days of use } \\
\cline { 2 - 3 } Concentration $(\mathrm{mg} / \mathrm{mL})$ & Control & Experimental \\
\hline 2.50 & 64.81 & 68.47 \\
1.25 & 63.99 & 66.00 \\
0.625 & 66.23 & 67.37 \\
0.312 & 66.84 & 67.66 \\
0.156 & 58.87 & 59.50 \\
\hline
\end{tabular}

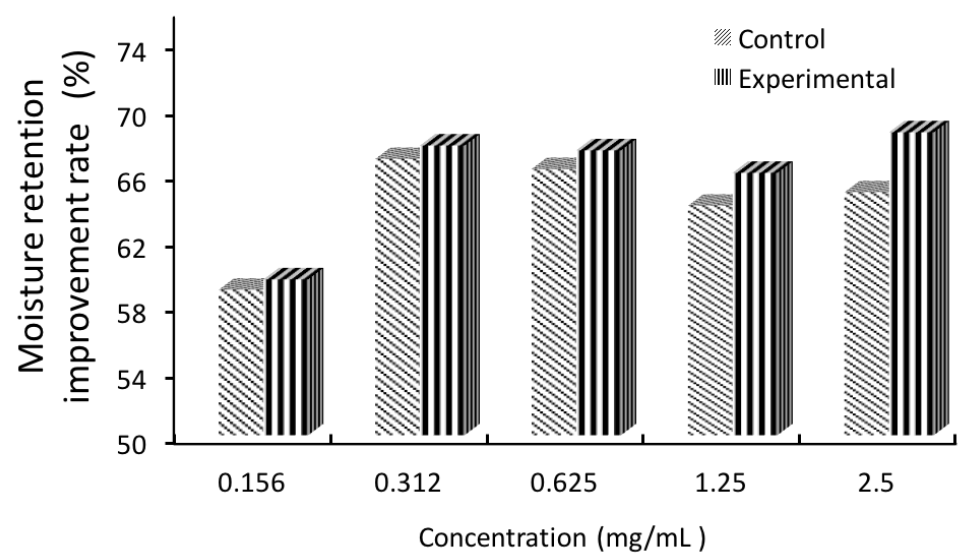

Figure 9. Whitening effect of the green onion root extract after 30 days of use

Whitening improvement rate $=\frac{\text { Experimental Group-Control Group }}{\text { Control Group }} \times 100 \%$

Table 5. Whitening effect improvement rate of the green onion root extract at different concentration after 30 days of use

\begin{tabular}{llllll}
\hline Concentration $(\mathrm{mg} / \mathrm{mL})$ & 2.50 & 1.25 & 0.625 & 0.312 & 0.156 \\
\hline $\begin{array}{l}\text { Whitening effect } \\
\text { improvement rate (\%) }\end{array}$ & 5.6 & 3.1 & 1.7 & 1.2 & 1.1 \\
\hline
\end{tabular}




\section{Formula design and product development}

With the rise of environmental awareness, many people have started to pay attention to the safety of skincare products. We all have heard the serious pollution and damage imposed upon the environment by skincare products made of chemical raw materials, such as environmental hormones. Such skincare products also harm human body at various degrees. Therefore, natural and environmentally-friendly products are preferred by consumers.

The above experiments confirmed that the green onion root extract has whitening, moisturizing and anti-aging effects and does not trigger cytotoxic reactions and allergic reactions. Thus, it is suitable to add the green onion root extract to cosmetics as a raw material for skincare products. We have chosen masks containing the green onion root extract as our preliminary product, and are seeking a manufacturer to develop the product with us through an industrialacademic collaboration program to commercialize the skincare product containing green onion root extract.

\section{Moisturizing and whitening mask with green onion root extract:}

First, the green onion root extract was added to the formula of the moisturizing and whitening masks. The masks were tried out by the research team, students and their family. We adjusted the formula for more than 20 times and compared the formulas without the green onion root extract (control group) with the formula containing 10\% green onion root extract (experimental group) (Table 6), and then checked if there were any differences in terms of whitening and moisturizing effects after 30 days of use.

Table 6. Moisturizing and whitening mask formula containing the green onion root extract (control group: without green onion root extract)

\begin{tabular}{|l|l|}
\hline INCI Name & $\mathbf{( \% )}$ \\
\hline Water & TO 100 \\
\hline Allium fistulosum root extract(10\%) & 2 \\
\hline Glycerin & 2 \\
\hline Propylene Glycol & 2 \\
\hline Butylene Glycol & 1.5 \\
\hline Jojoba Wax PEG-120 Esters & 0.8 \\
\hline Cucumis Sativus (Cucumber) Fruit Extract & 0.5 \\
\hline Panthenol & 0.5 \\
\hline Glycereth-7 & 0.5 \\
\hline Phenoxyethanol & 0.2 \\
\hline Saccharomyces Lysate Extract & 0.1 \\
\hline Acrylates/ C10-30 Alkyl Acrylates Crosspolymer & 0.1 \\
\hline Arginine & 0.1 \\
\hline Sodium Hyaluronate & 0.1 \\
\hline Allantoin & 0.1 \\
\hline Aloe Barbadensis Leaf Juice & 0.1 \\
\hline Xanthan Gum & 0.08 \\
\hline Hydrolyzed Hyaluronic Acid & 0.08 \\
\hline Tremella Fuciformis Sporocarp Extract & 0.08 \\
\hline Glycyrrhiza Glabra (Licorice) Root Extract & 0.05 \\
\hline Caprylhydroxamic Acid & 0.03 \\
\hline Capryl glycol & 0.018 \\
\hline Fragrance & 0.005 \\
\hline Chlorphenesin & 0.0012 \\
\hline
\end{tabular}

After 30 days of observation, the moisture retention values of the 20 subjects are shown in Table 7 and Figure 10, and the whitening effect values are shown in Table 8 and Figure 10. After 30 days of use, the moisturizing and whitening mask containing $10 \%$ of the green onion root extract was able to improve the moisture retention rate and whitening effect by $7.65 \%$ and $1.29 \%$, respectively (Table 8). 
Table 7. Average moisture retention and whitening effect data after 30 days of use

\begin{tabular}{|c|c|c|c|c|c|}
\hline \multirow{3}{*}{$\begin{array}{l}\text { Moisture } \\
\text { retention rate (\%) }\end{array}$} & \multicolumn{2}{|c|}{ After 30 days of use } & \multirow{3}{*}{$\begin{array}{l}\text { Whitening } \\
\text { effect }(\%)\end{array}$} & \multicolumn{2}{|c|}{ After 30 days of use } \\
\hline & Control & Experimental & & Control & Experimental \\
\hline & 57.5 & 61.9 & & $\begin{array}{l}54.1 \\
\end{array}$ & 55.1 \\
\hline
\end{tabular}

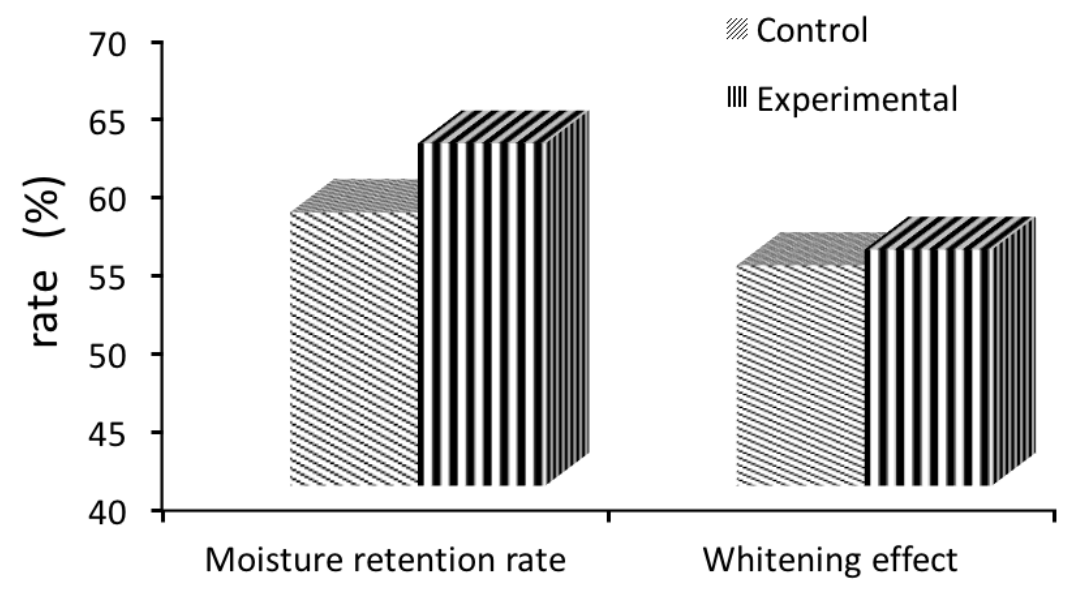

Figure 10. Moisture retention effect and whitening effect of the moisturizing and whitening mask containing the green onion root extract

Table 8. Improvement rates for whitening effect and moisturizing retention after using the moisturizing and whitening mask containing the green onion root extract

Improvement rate $(\%)$

Moisture retention Whitening effect

$7.65 \quad 1.29$

\section{CONCLUSIONS}

The above experimental results indicated that the DPPH radical scavenging ability, $\mathrm{Fe}^{2+}$ chelating ability, superoxide anions scavenging ability and melanin synthesis inhibition ability of the green onion root extract can achieve more than $80 \%$ of that of BHT and vitamin C. Moreover, the moisture retention effect and whitening effect were improved by $22.7 \%$ and $5.6 \%$, respectively, after 30 days of use.

The moisture retention effect and whitening effect of the moisturizing and whitening mask were improved significantly after the addition of the green onion root extract. As a result, based on this study, the green onion root extract can be added to cosmetic formulas as a natural raw material for skincare products.

This outcome can be added to teaching materials of various courses, such as cosmetics preparation, independent study, on-campus internship, and can enhance the students' interests and skills in cosmetics preparation and achieve the effects of diverse learning. The teachers and students will also fulfill their local social responsibility, assist in innovation and development of local industry and be pioneers of the University Social Responsibility Project. The university can also reuse the resource and make green life a reality to develop green economy and implement ecological concept.

RESUMO: Neste estudo, restos de raízes de cebolinhas Sansing, cultivadas sem produtos químicos tóxicos no município de Sansing, Condado de Ilan, Taiwan, foram utilizadas como matéria-prima de produtos para a pele. A matéria-prima foi extraída das raízes de cebolinha por ultrassom em um ambiente de baixa temperatura, seguro e livre de poluição. Esperamos desenvolver produtos de limpeza e outros produtos para cuidados faciais produzidos com essa matéria-prima natural, ecologicamente correta, segura e acessível, para 
que pessoas com pele sensível também possam usar esses produtos. Também esperamos que este estudo possa contribuir para a economia circular e alcançar o objetivo da inovação ecológica, reciclando restos das raízes. Em termos de anti-oxidação, a capacidade de sequestro do radical livre DPPH de $2,5 \mathrm{mg} / \mathrm{mL}$ de extrato de raiz de cebolinha foi equivalente a $98 \%$ de $1 \mathrm{mg} / \mathrm{mL}$ de BHT; a capacidade quelante do $\mathrm{Fe} 2+$ foi equivalente a $87,0 \%$ de $0,02 \mathrm{mg} / \mathrm{mL}$ de EDTA; a capacidade de sequestro de ânions superóxidos de $2,5 \mathrm{mg} / \mathrm{mL}$ de extrato de raiz de cebolinha foi equivalente a $84,2 \%$ de $1 \mathrm{mg} / \mathrm{mL}$ BHT e $80,4 \%$ de $0,05 \mathrm{mg} / \mathrm{mL}$ de vitamina C. No que diz respeito à inibição da síntese de melanina, a capacidade do extrato de raiz de cebolinha de inibir o dopacrômio, o metabolito intermediário de melanina, foi positivamente correlacionada com a sua concentração, ou seja, quanto maior a concentração do extrato de raiz de cebolinha, maior a capacidade de inibição. O IC50 de extrato de raiz de cebolinha foi de $1,83 \mathrm{mg} / \mathrm{mL}$, enquanto que, por comparação, o IC50 de vitamina C foi de 0,62 $\mathrm{mg} / \mathrm{mL}$. Além disso, de acordo com o ensaio de sobrevivência celular, nenhum efeito citotóxico foi observado com o aumento da concentração do extrato de raiz de cebolinha. $\mathrm{O}$ efeito de branqueamento melhora após 30 dias de ensaio. A melhoria foi de 5,6\% para $2,5 \mathrm{mg} / \mathrm{mL}$ de extrato de raiz de cebolinha, $3,1 \%$ para $1,25 \mathrm{mg} / \mathrm{mL}$ de extrato e $1,7 \%$ para $0,625 \mathrm{mg} / \mathrm{mL}$ de extrato. A retenção de umidade também melhorou depois de 30 dias de teste. A taxa de melhoria de retenção de umidade foi de $22,7 \%$ para $2,5 \mathrm{mg} / \mathrm{mL}$ de extrato de raiz de cebolinha, $21,6 \%$ para $1,25 \mathrm{mg} / \mathrm{mL}$ de extrato, e $15,4 \%$ para $0,625 \mathrm{mg} / \mathrm{mL}$ de extrato.Com base nas experiências efetuadas, o extrato de raiz de cebolinha obtida por ultrassom não só não causa alergia nem irritação da pele, mas também demonstrou atividade anti-envelhecimento, inibição da síntese de melanina, capacidade de branqueamento e retenção de umidade. Os resultados mostraram que o extrato de raiz de cebolinha pode melhorar a retenção de umidade e efeito de branqueamento da máscara.

PALAVRAS-CHAVE: Raiz De Cebola Verde. Extração. Economia circular. Anti-oxidação Antienvelhecimento. Branqueamento. Cosméticos.

\section{REFERENCES}

CHANG, T. C.; DUAN, P. F.; LIN, S. F. Studies on Antioxidant Activity of Welsh Onion (Allium fistulosum) in Taiwan. MACKAY J., v. 8, p. 115-133, 2011.

CHEN, J. H.; TSAI, S. J.; CHEN, H. I. Welsh onion (Allium fistulosum L.) extracts alter vascular responses in rat aortae. Cardiovascular pharmacology. v. 33, p. 515-520, 1999.

CHIOU, P. C. Effect of different fertilization managements on Allium fistulosum growth, soil chemical properties, enzyme activities, and microbial communities. Master's Degree in Argicultural Chemistry, National Taiwan University, Taiwan, 2010.

DINIS, T. C. P.; MADEIRA, V. M. C.; ALMEIDA, L. M. Action of phenolic derivatives (acetanibophen, salicylate, and 5-aminosalicylate) as inhibitors of membrane lipid peroxidation and as peroxyl radical scavengers. Arch. Biochem. Biophys., v. 315, p. 161-169, 1994. https://doi.org/10.1006/abbi.1994.1485

FRIED, R. Colorimetric determination of xanthine dehydrogenase by tetrazolium reduction. Anal. Biochem., v. 16, p. 427- 432. 1966. https://doi.org/10.1016/0003-2697(66)90224-7

GREATENS, A.; HAKOZAKI, T.; KOSHOFFER, A.; EPSTEIN, H.; SCHWEMBERGER, S.; BABCOCK, G.; BOISSY, R. E. Effective inhibition of melanosome transfer to keratinocytes by lectins and niacinamide is reversible. Experimental Dermatology, v. 14, n. 7, p. 498-508, 2005. https://doi.org/10.1111/j.09066705.2005.00309.x

HSIAO, W. C. Effects of aqueous extract from Welsh onion green leaves on intracellular lipid accumulation in RAW264.7 macrophages. Master's Degree in Dept. of Biotechnolgy, Chia Nan University, 2004. 
HSU, T. H. The Study of Antioxdants in shallot by Supercritical carbon dioxide Extraction. Master's Degree in Graduate school of Health Industry Management, Ching Kuo Institute of Management and Health, 2012.

HUANG, C. C. Studies on Antimicrobial activity of Onion Extract. Master's Degree in Depart. Of Food Sci., Nat. PingTung University of Sci. and Tech., 1999.

HUANG, C. J. Effect of copper, zinc and selenium added to soil on their content in onion plant (Allium cepa, L) and antioxidation capability. Master's Degree in Dept. of Environmental Sci. and Occupational Safety and Hygiene, TaJen University, 2007.

HUANG, S. Y. Investigate the impact of Taiwan's northern and eastern candy commercially available sulfites in foods and sulfite residual of mung bean growth and root growth of onion. Master's Degree in Department of Biological Science and Technology, China University of Science and Technology, 2015.

JIANG, S. S. Studies on glutamyltranspeptidase from welsh onion (Allium fistulosum L.) Purification, properties and flavor enhancement effect. Master's Degree in Food Science and Biotechnology, National Chung Hsing University, Taiwan, 1992.

KAZUHO, A.; HIROSHI, S. Both oxidative stress- dependent and independent effects of amyloid $\beta$ protein are detected by 3-(4, 5-dimethylthiazol- 2-yl)-2, 5-diphenyltetrazolium bromide (MTT) reduction assay. Brain Research, v. 830, p. 146-154, 1999. https://doi.org/10.1016/S0006-8993(99)01421-3

KUNG, P. W. Studies on Cultivation of Organic Green Onions (Allium fistulosum L.). Master's Degree in Horticulture, National YiLan University, Taiwan, 2001.

LEE, K. T.; KIM, B. J.; KIM, J. H. Biological screening of 100 plant extracts for cosmetic use (I): inhibitory activities of tyrosinase and dopa- autooxidation. Int. J. Cosmet. Sci., v. 19, p. 291-298, 1997.

https://doi.org/10.1046/j.1467-2494.1997.171725.x

https://doi.org/10.1111/j.1467-2494.1997.tb00193.x

LERNER, A. B.; FITZPATRICK, T. B. Biochemistry of melanin formation. Physiological Reviews, v. 30, n. 1, p. 91-126, 1950. https://doi.org/10.1152/physrev.1950.30.1.91

LIN, S. S. ANTI-INFLAMMATORY EFFECTS OF AQUEOUS EXTRACT FROM WELSH ONION GREEN LEAVES. Master's Degree in Dept. of Biotechnolgy, Chia Nan University, 2003.

MAYER, A. M. Polyphenol oxidases in plants-recent progress. PHYTOCHEMISTRY, v. 26, n. 1, p. 11-20, 1986. https://doi.org/10.1016/S0031-9422(00)81472-7

MURAI, M.; YOSHINO, A.; JITSUKAWA, S.; UCHIDA. T. Studies on the tillering factors of welsh onion (Allium fistulosum L.). Bull. Chiba Found. Seed \&St. Farm. v. 3, p. 21-42. 1981.

RAJU, M.; VARAKUMAR, S.; LAKSHMINARYANA, R.; KRISHNAKANTHA, T. P.; BASKARAN, V. Carotenoid composition and vitamin A activity of medicinally important green leafy vegetables. Food Chemistry, v. 101, p. 1598-1605, 2007. https://doi.org/10.1016/j.foodchem.2006.04.015

SU, Y. J. Effects of raw Welsh onion extracts on endothelium- derived nitric oxide production in human umbilical vein endothelium cell. Master's Degree in Biotechnology, Chia Nan University, Taiwan, 2003.

WU, H. C. Effect of light and cultivation method on growth and volatile compounds of green onion (Allium fistulosum L.). Master's Degree in Agronomy, National Taiwan University, Taiwan, 2010. 
YAMAGUCHI, T.; TAKAMURA, H.; MATOBA T. T.; TERAO. J. HPLC method for evaluation of the free radical- scavenging activity of foods by using 1,1-diphenyl-2-picrylhydrazyl. Biosci. Biotechnol. Biochem., v. 62, p. 1201-1204, 1998. https://doi.org/10.1271/bbb.62.1201

YAMASAKI, A.; TANAKA, K; YOSHIDA, M.; MIURA, H. Induction of devernalization in Mid-season flowering cultivars of Japanese bunching onion (Allium fistulosum L.) by high day temperature. J. Japan. Soc. Hort. Sci., v. 69, p. 611-613, 2000. https://doi.org/10.2503/jjshs.69.611

ZHONG, W. X. Studies on bacterial soft rot disease of welsh onion in Taiwan. Master's Degree in Plant Pathology, National Chung Hsing University, Taiwan, 1993. 